\title{
RABOTNITSA AND BEZDEL'NITSA: RUSSIAN FEMININITIVES WITH SUFFIX -NITSA
}

\section{Regina R. Guzaerova}

Kazan Federal University, Institute of Philology and Intercultural Communication E-mail: rguzaerova@gmail.com

\section{Drahomíra Sabolová}

Inštitút rusistiky, Filozofická fakulta Prešovskej Univerzity v Prešove

Vera A. Kosova

Kazan Federal University, Institute of Philology and Intercultural Communication

Recepción: 05/08/2019 Aceptación: 18/09/2019 Publicación: 23/10/2019

\section{Gitación sugerida:}

Guzaerova, R.R., Sabolová, D. y Kosova, V.A. (2019). Rabotnitsa and bezdel'nitsa: russian femininitives with suffix -nitsa. 3C TIC. Cuadernos de desarrollo aplicados a las TIC. Edición Especial, Octubre 2019, 300-315. doi: https://doi.org/10.17993/3ctic.2019.83-2.300-315

\section{Suggested citation:}

Guzaerova, R.R., Sabolová, D. \& Kosova, V.A. (2019). Rabotnitsa and bezdel'nitsa: russian femininitives with suffix -nitsa. 3C TIC. Cuadernos de desarrollo aplicados a las TIC. Special Issue, October 2019, 300-315. doi: https://doi.org/10.17993/3ctic.2019.83-2.300-315 


\section{ABSTRACT}

The article is concerned with the actual linguistic problem - the functioning of the designations of females with the suffix formant -ниц(a) / -nits(a) in modern Russian. The suffix -ниц(a) / -nits(a) is one of the most popular means of forming the derivational category of feminitivity, distinguished based on commonness of derivational meaning 'a female person belonging to the category of persons called a motivating noun'. The relevance of the study is determined by the increasing significance of female denominations as an object of linguistic research, as well as their activity in modern Russian media space. We understand media space as a global communication environment created by electronic means. The article has developed a classification of feminitives with the suffix -ниц(a) / -nits(a) based on the formal structure of a productive word. The language material for our study is 635 lexemes with the indicated suffix, selected from authoritative dictionaries of the modern Russian language, the National Corpora of the Russian language and the data from various Internet resources. The paper makes the conclusion about the stylistic universality of the female designations with the suffix -ниц(a) / -nits(a), that is, their ability to function in different styles of speech; lists social and linguistic factors under the influence of which the changes in this point of the derivational system occur.

\section{KEYWORDS}

Feminitivity, Word Formation, Feminitive, Gender, Neology, Derivation Category. 


\section{INTRODUCTION}

One of the most used means of the derivation category of feminitivity in the Russian language is the suffix formant -ниц(a) / -nits(a). This derivational type in terms of the category we are interested in - feminitivity - has a modification meaning 'a female belonging to the category of persons called a motivating noun'. The meaning of "a person based on gender" is distinguished following on from juxtaposition of the semes of "male" and "female" and correlates with the grammatical meaning of gender, with the exception of the group of personal generic nouns and masculine nouns with the lost seme "male", such as врач/ vrach (doctor) (Novikova, 2004; Igartua \& Santazilia, 2018). Such names usually designate a profession, a position, a specialty.

The category of personal nouns is traditionally one of the most significant objects of linguistic research, especially in relation to the gender (Safin et al., 2015; Bokale, 2010; Nikunlassi et al., 2011), including the derivational aspect (Makleeva et al., 2017; Makleeva et al., 2016; Neri \& Schuhmann, 2014), which determines the relevance of the present research.

Feminine personal nouns, as a rule, are formed from masculine nouns due to social factors and historical reasons. Until recently, the way to call women a separate word was the only possible way: жнец - жница / zhnets - zhnitsa (a reaper), ткач - ткаха / tkach -tkakha (a weaver), золотарь - золотарица/ zolotar' - zolotaritsa (a goldsmith), and in the 19th century a new tendency to generalize the names of persons in the form of a masculine gender did arise: поэт / poet, живописец/ zhivopisets (a poet, a painter). In the 20th century, this trend continued to develop rapidly, which led to a decrease, firstly, in the number of female derivatives being formed, and, secondly, in the frequency of using feminitives already existing in the language (feminine gender-specific profession title or other affiliation) (YankoTrinitskaya, 1966).

Derivative words with the female meaning have been studied well in diachronic and synchronous aspects: see the works by Novikova (2004), Zemskaya (2011), Berkutova (2017), Protchenko (1984), Yanko-Trinitskaya (1966); a description of 
the morphemic means of expressing the meaning of femininity is presented in Russian Grammar (Novikova, 2004; Zemskaya, 2011; Berkutova, 2017; Protchenko, 1984; Shvedova, 1980; Yanko-Trinitskaya, 1966).

The category of feminitivity is distinguished based on the generalized derivational meaning of 'female'. In terms of the semantics of the original word and the derivative, feminitivity is the derivational category of the modification type, since the main meaning of the producing word in the derivative is preserved, only the seme denoting female is added. The denominations of women form an independent derivation category according to the criterion formulated by R.S. Manucharyan: "In this language, one or another derivation category exists if the corresponding word-forming meaning is expressed by formal indicators, among which there is at least one that expresses - within the indicated framework - this meaning only (Manucharyan, 1981).

The derivational models of the category of word-formation of femininity are extremely diverse: Russian Grammar captures 10 basic modification types with a general meaning of femininity (Shvedova, 1980) among which there are those that express exclusively femininity.These include the models with suffixes of foreign origin -ш(a) / - $\boldsymbol{s h}(\boldsymbol{a})$ : авторша / avtorsha, архитекторша / arkhitektorsha, кассирша / kasirsha; -есс(а) / ess(a): стюардесса / styuardessa, пилотесса / pilotessa; -ис(a) / -is(a): актриса/ aktrisa, лектриса / lektrisa. The most popular of them is a derivational type with the suffix -ш(a)l $\boldsymbol{s} \boldsymbol{h}(\boldsymbol{a})$ which finds productivity mainly in colloquial speech: блогерша / blogersha, хакерша/ khakersha, менеджерша/ menedzhersha, байкерша / baikersha. The suffixes -к(a) / -k(a), -ин(я)/-ын(я) /in(ya), yn(ya), -иц(а) / its(a) derive the words to designate women (активистка / aktivistka, рабыня / rabynya, княгиня / knyaginya, мастерица / masteritsa, гостья / gost'ya) and female animals (голубка / golubka, гусыня / gusynya, волчица / volchitsa, летунья/letun'ya). The primordial Slavonic suffixes -ин(a) / -in(a) and -ниц(a) / -nits(a) express exclusively the meaning of feminitivity within the nominal category of persons (синьорина/ sin'yorina, учительница / uchitelnitsa). 
The object of our study is the feminitives with the suffix formant -ниц(a)/-nits(a) and their functioning in the modern Russian media space which is a special place for language implementation, generating new language forms. The influence of the communicative environment, namely the Internet, on constructing gender concepts in the language becomes an object of studying by linguists often (Miftakhova et al., 2018; Miftakhova et al., 2017; Bussmann \& Hellinger, 2001; Chelak, 2019; Bochina et al., 2015).

\section{METHODOLOGY}

The language material is represented by 635 lexemes with the suffix -ниц(a) I -nits(a) and has been selected by a continuous excerption from authoritative dictionaries of the modern Russian language (see Reverse Russian Dictionary, 1974; Kolesnikov, 2002; Yefremova, 2000). The analysis of the functioning of naming units denoting females in the language has been carried out based on material collected with the help of the NCRL (National Corpus of the Russian Language) (Russian National Corpus, 2019), media data and personal blogs on the Internet.

The research methods are based on: a) an integrated approach to the analysis of derived units; b) the analysis of the derivational structure and motivational relations; c) determining the specifics of functioning in speech.

\section{RESULTS AND DISCUSSION}

The suffix -ниц(a) / -nits(a) is one of the oldest means of expressing the derivation category of feminitivity in the history of the Russian language. Specialist in the field of historical word formation Azarkh (2007) writes: "The most productive model of correlation of naming units that designate persons on the basis of gender in the Old Russian period is the opposition of derivatives ending in -(bH) икъ and -(ьн)ица: ключьникъ / klyuchnik- ключьница / kluchnitsa". This type is 
common in many Slavonic languages: Ukrainian (монтажниця, сортувальниця, заступниця), Byelorussian (ўладальніца, вучаніца, чараўніца), Polish (robotnica, tanezcnica), etc.

In the Russian language the suffix -ниц(a)/-nits(a):

1) Is added to the masculine stems ending in the suffix-тель/tel' with the meaning 'a person classified according to an action being performed': воспитательница/ vospitatelnitsa (educatress), воительница / voitelnitsa (warrior), долгожительница / dolgozhitelnitsa (long-liver), писательница / pisatelnitsa (authoress), радиослушательница / radioslushatelnitsa (broadcast listener), свидетельница / svidetelnitsa (witness), учредительница / uchreditelnitsa (foundress), etc. (259 words - 41\%). According to the type of formal relations, the feminine word has a more compound form compared with the masculine noun (Zemskaya, 2011);

2) Correlates with the masculine naming units ending in -ник/ -nik. The meaning of the suffix is 'one who is associated with the activity, profession, implement or material of labor that is specified in the stem'. It concerns the derivatives such аs бортпроводница/ bortprovodnitsa (a stewardess), воспитанница / vospitannitsa (a pupil), десятиклассница / desyatiklassnitsa (a tenth grader), завистница / zavistnitsa (an envious lady), изменница/ izmennitsa (a traitor), помощница/ pomoshchnitsa (an assistant), художница / khudozhnitsa (an artist), etc. (376 words - 59\%). In this case, the feminine noun is the same in complexity with the masculine noun (Zemskaya, 2011).

Unlike other derivational types of the feminitivity category, for example, with the suffix $-\mathrm{\kappa}(\mathrm{a}) /-k(a)$, the suffix -ниц(a) /-nits(a) is associated exclusively with the above stems, which determines the lexical and semantic composition of this group of feminitives in which the job titles predominate. This allows the conclusion that the word-forming pattern with the suffix -ниц(a)/-nits(a) primarily is used in naming units related to human activity, professional one. 
According to the stylistic characteristics, 177 naming units of female ending in -ниц(a)/-its(a) (28\%) are marked as colloquial, 5 - as slang (0.8\%), 17 - as low colloquial (2.8\%), among which:

1) The feminitives are colloquial, and the masculine correlates are stylistically neutral (водитель / voditel' - водительница / voditelnitsa, заместитель / zamestitel' - заместительница / zamestitelnitsa, обозреватель / obozrebatel обозревательница / obozrevatelnitsa, охранник / okhrannik - охранница / okhrannitsa);

2) Both correlates are colloquial (изобразитель / izobretatel' изобразительница / izobretatelnitsa, напарник /naparnik - напарница / naparnitsa, обожатель / obozhatel'- обожательница / obozhatelnitsa).

33 feminitives with the suffix formant -ниц(a)/ -nits(a) are characterized in dictionaries as bookish, 10 - as official, 4 belong to high style, 2 - to church vocabulary (only 7.8\%), other lexemes belong to neutral style of speech (392 words $-62 \%$ ). One can argue that the suffixal pattern -ниц(a)-/ nitz(a) is the most universal means of expressing the meaning of feminitivity, and the derivatives with this formant are regarded by native speakers as stylistically neutral. The feminitives ending in -ниц(a) / - nits(a) are common in various functional styles of speech, from scientific communication (1) and journalism (2) to the language of fiction (3), and most often do not possess additional discursive marking:

(1) Известная исследовательница творчества Кракауэра Гертруда Кох обращает внимание в этой связи на один важный аспект: ««асса» больше не выражает ничьих частных интересов, она стала массой потребителей (Russian National Corpus, 2019);

(2) Сестра юного убийцы, 15 лет от роду, проходит по делу как свидетельница вместе с двумя остальными подростками, не принимавшими участия в жестокой расправе (Russian National Corpus, 2019); 
(3) И если позволяло время, монтажница звала её, она подсаживалась к монтажному столу (Russian National Corpus, 2019).

However, at the present time, feminitives remain outside the official business style of speech: the profession title учительница/ uchitelnitsa (teacher) is perhaps one of the most commonly used feminitives, however, the name of the AllRussian contest "У читель года" ("Teacher of the Year") and the honorary title “Заслуженный учитель России" ("Honored Teacher of Russia") exist only in masculine. The ability of the masculine form to call a person regardless of gender, and to unite men and women in the plural provides a similar opportunity to unify the naming units designating males and females in the official discourse. This is most consistently expressed in the language of jurisprudence where compliance with terminology requirements, in particular: unity, systematicity and impersonal character, implies the use of one common naming unit, for example, свидетель/ svidetel' (a witness), but not свидетельница/ svidetel'nitsa, that is often found in journalistic style and fiction.

At the present stage of the development of civilization, labor is the foundation of all human life. The level of engagement in labor activity in the largest sense of all adult members of society is higher than ever, which makes the profession one of the basic personal values. In the new conditions regulated by the economic laws of the market, the issue of professional identification and self-representation in the sociocultural and linguistic context is highly relevant. The use of feminitives and the formation of new ones according to the patterns existing in the language can be called one of the manifestations of linguistic reflection which is understood as the individual's ability to use the language consciously, to regulate speech and choose the appropriate communicative strategy (Troshina, 2010).

Thus, the use of existing female naming units with the suffix -ниц(а)/-nits(a) (начальница/nachalnitsa, правозащитница/pravozashchitnitsa, заместительница I zamestitelnitsa), the formation of new ones according to the same wordbuilding pattern (пользовательница/ polzovatelnitsa, анимешница/ animeshnitsa, землеустроительница/zemleustroitelnitsa) and the rethinking of feminitives in the 
language in a changing sociocultural context ( the word тысячница/ tysyachnitsa - earlier: "an advanced woman-worker, a collective farmer who performs with ten or more norms per working day" (Bochina et al., 2015); now it means: "a woman who has more than a thousand subscribers to her online blog") are aimed at solving several linguistic and communicative problems:

1) Language representation of women as qualified specialists and professionals whose importance can hardly be overestimated because of the importance of the profession in modern society;

2) Compliance with the grammar norm in the agreement of personal feminine nouns with the past tense of the verb in the form of feminine. It permits one to avoid the constructions like исследователь рассказала..., учитель получила... which, despite their common usage, still belong to the style of everyday conversation;

3) An indication of the gender via a female suffix as a part of the language game. For example, in the profile of a personal page on the Instagram social platform, the following form was used: красивая девочка электромонтажница/ krasivaya devochka elektromontazhnitsa (a beautiful electrician girl) (Instagram, 2019).

The suffixal type -ниц(a)/ -nits(a) belongs to the unstable part of the wordformation system of the Russian language where dynamic shifts occur under the influence of various, sometimes conflicting social and linguistic factors: seeking for the uniformity of naming people by profession, the language habit of combining lexical grammatical gender, the need to indicate the gender of a person in certain speech situations, the variety of word-forming patterns of the category of feminitivity and the unsystematic nature of their use in the field of non-usual vocabulary. 


\section{SUMMARY}

The derivation category of feminitivity is characterized by a variety of derivational models. The suffixal type in -ниц(a) / -nits (a) is one of the most highly productive in the category of feminitivity, which is proved by the analysis of 635 lexemes with this suffix that function in modern Russian. The prevailing part of the presented naming units has the semantics of the producer of the action and name women by professional and social affiliation. The suffix -ниц(a)/-nits(a) has a limited compatibility and is added either to the masculine stems ending in -тель/-tel' or to the stems ending in -ник/-nik with the apocope of the latter.

The word-formation type with the suffiх-ниц(a) /-nits(a) predominantly functions in a neutral style of speech (62\% of lexemes), which indicates the stylistic universality of the naming units formed according to this word-building pattern.

\section{CONCLUSIONS}

Thus, the word-formative pattern with the suffixal formant ниц(a) /-nits(a) is one of the most highly productive means of the word-formation category of femininity, which help designate female by professional, social and other belongings, mainly to the neutral layer of modern Russian vocabulary. A controversial nature of the use and formation of feminitives determines the prospect of further studies of word-formation processes taking place in modern Russian.

\section{ACKNOWLEDGMENTS}

The work is performed according to the Russian Government Program of Competitive Growth of Kazan Federal University. 


\section{REFERENCES}

Azarkh, Y. S. (2007). The Problem of the Connection of Word Formation and Morphogenesis in the History of the Russian Language (The Noun): Dissertation for Doctor of Philology. Moscow.

Berkutova, V. (2017). Feminine Gender-Specific Job Title in the Russian Language: Linguistic Aspect. St. Petersburg. Retrieved from https://www.psypart.com/ feminitivy-lingvisticheskii-aspect (Accessed February 05, 2019).

Bochina, T. G., Miftakhova, A. N., \& Malikov, A. Z. (2015). Internet as a resource of socio-linguistic researches. Social Sciences, 10(5), 626-632. doi: https://doi.org/10.3923/sscience.2015.626.632

Bokale, P. (2010). The formation of feminine nouns in Bulgarian. The results of a field investigation. Езиков свят-Orbis Linguarum, (2), 102-119. Retrieved from https:/ / www.ceeol.com/search/article-detail?id=242338

Bussmann, H., \& Hellinger, M. (2001). Doing gender in Russian. Gender across languages. An International Handbook. Dordrecht: Benjamins, 253-282.

Chelak, E. A. (2019). Feminine Gender-Specific Job Titles in the Discourse of Internet Communication. International Research fournal, 12(78) Part 2. - p. 197200. Retrieved from https://research-journal.org/languages/feminitivy-vdiskurse-internet-kommunikacii/ (Accessed May 06, 2019).

Igartua, I., \& Santazilia, E. (2018). How Animacy and Natural Gender Constrain Morphological Complexity: Evidence from Diachrony. Open Linguistics, 4(1), 438-452. doi: https://doi.org/10.1515/opli-2018-0022

Instagram. Retrieved from https://www.instagram.com/victoria_golubeva/ (Accessed May 26, 2019).

Kolesnikov, N. P. (2002). Explanatory Dictionary of the Designations of Women. Astrel. 
Makleeva, E. A., Zhike, Y., \& Kosova, V. A. (2017). Peculiarities of WordFormation of Derived Nouns with the Suffix-Yx-In Modern Russian Language. Ad Alta-fournal of Interdisciplinary Research, 7(2), 62-63.

Makleeva, E., Kosova, V., \& Miao, S. (2016). Jargon compressive nominations from the point of view of the Russian linguistic world-image. Fournal of Language and Literature, 7(1), 199-202. Retrieved from http://dspace.kpfu.ru/xmlui/bitstream/handle/ net/145395/SGOPUS20 780303-2016-7-1-SID 85002654045 -a 1. pdf;jsessionid $=424381$ A1476FA1AC3EB6015E1C3FA9B5? sequence $=-1$

Manucharyan, R. S. (1981). Word-Formation Meanings and Forms in Russian and Armenian: [Textbook for Philological Faculties].

Miftakhova A., N., Bochina T. G., \& Zhuravleva Yevgeniya, A. (2018). Gender interpretation of Russian lexeme БАБА/BАВA in Internet discourse. Herald NAMSCA, 3, 1118-1121.

Miftakhova, A. N., Bochina, T. G., \& Sergeeva, E. (2017). Gender Interpretation of Woman Lexeme in Internet Discourse. Fournal of Pharmacy Research, 11(11), 1336-1340. Retrieved from http://jprsolutions.info/files/ final-file-5alad0bd2da924.49943889.pdf

Neri, S., \& Schuhmann, R. (2014). Gender and word formation: The PIE gender system in cross-linguistic perspective. Kollektivum und Femininum: Flexion oder Wortbildung. Zum Andenken an Fohannes Schmidt, Leiden: Brill, 199-231.

Nikunlassi, A., Rissanen, M., Nevalainen, T., \& Saari, M. (eds). (2011). Gender in Grammar and Cognition. II: Manifestations of Gender. Trends in Linguistics. Studies and Monographs, 124, Berlin: Mouton de Gruyter, 771791. 
Novikova, M. R. (2004). The Features of Functioning of the Suffixes with the Meaning of Female in Slavonic Languages. Grammatical Categories and Units: Collection of Scientific Articles on the 75th Anniversary of A.B. Kopelovich. - Vladimir: VSPU, 224 p.

Protchenko, I. F. (1984). The Russian Language: The Problems of Learning and Development. Pedagogy, 222 p.

Reverse Russian Dictionary. (1974). About 125,000 Words. Soviet Encyclopedia, 944 p.

Russian National Gorpus. (2019). Retrieved from http://www.ruscorpora. ru/new/en/index.html (Accessed May 06, 2019)

Safin, I. K., Kolosova, E. I., \& Bychkova, T. A. (2015). Representation of gender concepts in the Russian and Polish languages. The Social Sciences (Pakistan), 10(5), 562-565. Retrieved from http://dspace.kpfu.ru/ xmlui/bitstream/handle/net/140029/SCOPUS18185800-2015-10-5SID84938696304-a1.pdf?sequence=-1

Shvedova, N. Y. (editor-in-chief) (1980). Russian Grammar. V. 1. Phonetics. Phonology. Stress. Intonation. Word Formation. Morphology. Nauka, 789 p.

Troshina, N. N. (2010). Language Culture and Language Reflection [Text]: An Analytical Review. Russian Academy of Sciences, Institute of Scientific Information for Social Sciences. Moscow: RAS ISISS.

Yanko-Trinitskaya, N. A. (1966). Designation of Females by Nouns of Female and Masculine Gende. Development of Word Formation of the Modern Russian Language. Nauka, 167-210.

Yefremova, T. F. (2000). The New Dictionary of the Russian Language. Explanation and Derivation: 136000 Entries. About 250,000 Semantic Units: [In 2 Volumes]. 
3C TIC. Cuadernos de desarrollo aplicados a las TIC. ISSN: 2254-6529

Zemskaya, E. A. (2011). Modern Russian. Word Formation: Textbook (3 $3^{\text {rd }}$ ed.), Extended. Flint: Nauka. 
Edición Especial Special Issue Octubre 2019 DOI: https://doi.org/10.17993/3ctic.2019.83-2.300-315 